\title{
伊良部島長山の浜の侵食実態とBG モデルによる海浜安定化検討
}

\author{
Beach Changes of Nagayama-no-hama Beach on Irabu Island and Numerical Simulation \\ Using BG Model to Stabilize Shoreline
}

\author{
宇多高明 ${ }^{1}$. 宮原志帆 ${ }^{2}$. 宜保 勝 $^{3}$ - 勢理客 武 $^{3}$. 奥間 章 $^{3}$ \\ 嶺井治男 ${ }^{4} \cdot$ 三波俊郎 $^{2} \cdot$ 芹沢真澄 $^{5} \cdot$ 菊池昭男 $^{6}$ \\ Takaaki UDA, Shiho MIYAHARA, Masaru GIBO, Takeshi SERIKYAKU, Akira OKUMA \\ Haruo MINEI, Toshiro SAN-NAMI, Masumi SERIZAWA and Akio KIKUCHI
}

\begin{abstract}
The Irabu Bridge connects Miyako Island to Irabu Island and it is now under construction. A causeway was constructed between the foot of the bridge and its central part using land reclamation method, resulting in formation of wave shelter zone on both sides of the causeway. After the construction of the causeway, marked beach changes occurred on the reef coast, and egg-laying sites of sea turtles were lost. The BG model was applied to investigate the stabilization method of the beach. Most suitable measure was to use groins as well as the beach nourishment.
\end{abstract}

\section{1. まえがき}

伊良部大橋は, 宮古島とその西に位置する伊良部島を 結ぶ橋梁であり，現在建設が進められている。この橋の 伊良部島近傍の一部は, 橋梁形式ではなく埋立方式で造 られている。埋立部の長さはそのほぼ中央に $70 \mathrm{~m}$ の開口 部を有して全体で $670 \mathrm{~m}$ である。伊良部島と宮古島の間 の海峡部では主に冬季の北西方向からの入射波と, 夏季 の南側からの入射波の作用を受けるが, 上記埋立地が造 られたたことにより波の遮蔽域が形成された。従来, 伊 良部島の南東端に位置する長山の浜はこれら両方向から の波の作用を受けてバランスしていたが, 埋立地の南側 では北西方向からの波の作用がなくなり，南側からの波 の作用のみとなって南部海岸から埋立地方面への沿岸漂 砂が誘起された。一方, 埋立地の北側では南側からの波 の作用が埋立地建設による波の遮蔽効果により消失し, 北西方向からの入射波の作用のみとなった。主として南 側から沿岸漂砂によって運ばれた砂は埋立地の付け根に 大きなトンボロを造って堆積する一方, 南部では砂浜が 削り取られビーチロックが露出する状況となった。長山 の浜はアカウミガメの産卵地であったが, 砂浜消失によ って産卵地の消失が起きた。この状況の下で砂浜の回復 と, 伊良部大橋建設上の理由から橋梁取り付け部での堆

\begin{tabular}{|c|c|c|}
\hline 1 正会員 & 工博 & $\begin{array}{l}\text { (財) 土木研究センター常務理事なぎさ } \\
\text { 総合研究室長兼日本大学客員教授理工学部 } \\
\text { 海洋建築工学科 }\end{array}$ \\
\hline 2 & & 海岸研究室 (有) \\
\hline 3 & & $\begin{array}{l}\text { 沖䋲県土木建築部宮古土木事務所伊良部 } \\
\text { 大橋建設現場事務所 }\end{array}$ \\
\hline 4 & & 岩下建技コンサルタント \\
\hline 5 正 & & 海岸研究室 (有) \\
\hline 6 正会員 & & (有) コスタルテクノ \\
\hline
\end{tabular}

砂防止が求められている. 本研究では空中写真や汀線測 量デー夕を基に海浜変形機構を分析するとともに, 2010 年9月6日には現地踏査を行い, これらのデータを基に 芹沢ら（2006）によるBGモデル（Bagnold概念に基づく 海浜変形モデル）を用いて対策案の検討を行った。

\section{2. 伊良部島周辺の地形概況}

1985 年測量（海上保安庁水路部：No.6512-2）の海底 地形図より切り出した伊良部島南東部の詳細海底地形を 図-1に示す。海底地形図は, リーフの平坦面が2010年測 量 (沖縄県), リーフ平坦面よりも外側は1985年測量 （海上保安庁水路部：No.6512-2）であり，これらのデー 夕を接合して新たに作成した。伊良部島南東部には幅が 約 $1 \mathrm{~km}$, 南北方向の長さが約 $1.8 \mathrm{~km}$ のリーフが発達して

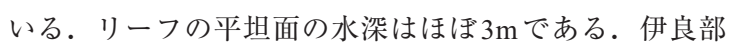
大橋の南 $1 \mathrm{~km}$ には橋軸とほぼ平行にリーフエッジが伸 び, そこで水深が $8 \sim 10 \mathrm{~m}$ まで急に落ち込んでいる. ま

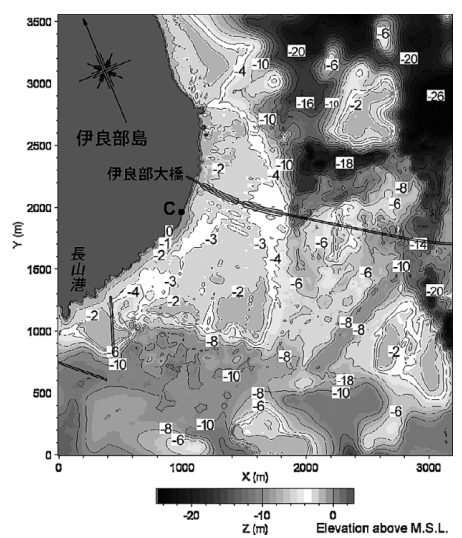

図-1 伊良部島南東部の海底地形 


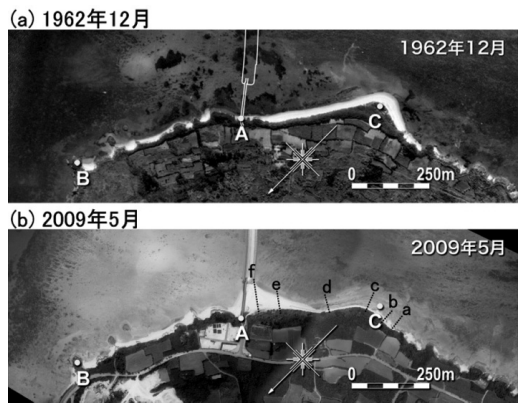

図-2 長山の浜の空中写真

たリーフエッジに沿って水深 $2 \mathrm{~m}$ のクレストが伸びてい る.リーフエッジの外縁を滑らかな線で結び，その法線 の方向角を読み取ると $\mathrm{S} 38^{\circ} \mathrm{W}$ となる.リーフエッジの外 側が急深であり，そこにほぼ直線状のリーフエッジが伸 びていることを考慮すれば，東シナ海からの卓越波浪は ほぼこの方向角を持って入射すると推定できる。また， このリーフエッジの東端にも深みがあり，この深みは北 東方向に「ハ」の字形に開いている。このためほぼ南西 方向からの入射波はこの深みを通過後，屈折して伊良部 大橋方向へ向かうと推定できる。リーフ南縁ではリーフ クレストの発達が良好であるのに対し，伊良部大橋の北 側ではクレストの発達はなく，伊良部島から東側では緩 やかな傾斜で深くなっている．このように伊良部大橋を 境とする，北東側と南側でのリーフ地形の相違は，伊良 部島南東部にあっては主に南西側からの波浪作用が著し く，これによってリーフが発達してきたことを意味する. 伊良部島南東部の長山の浜付近の詳細地形について調心゙ ると， $-1 \mathrm{~m}$ と $-2 \mathrm{~m}$ の等深線は海岸線とほぼ平行に延びる が，伊良部大橋の南西 $250 \mathrm{~m}$ 付近の C 点付近では海岸線に 対してこれらの等深線が突出している.この付近ではリ ーフの基盤面が露出している.

\section{3. 空中写真の判読と汀線変化}

長山の浜が写された空中写真を取得し，対象区域を拡 大することにより空中写真の判読を行った。空中写真は 1962 年 12 月 (米軍撮影：初回), 1972年3月, 1977年 11 月，1986年 10 月，1994年 9 月，2006年 7 月，2009年 5 月， 2009 年 12 月の 8 時期があるが，例えば，初回の 1962 年と 2009年 5 月の空中写真を図-2に示す．なお，各図では橋梁 予定線と海岸線との交点にAを，Aの北側に550m離れた 岩にBを，またAの南西 $450 \mathrm{~m} に \mathrm{C}$ を定める。まず図-2(a) で伊良部大橋の架橋予定線の北側区域の特徵を調べる と, 砂浜は $\mathrm{AB}$ 間にのみ分布し, $\mathrm{B}$ の北側は露岩域であっ た。また $\mathrm{AB}$ 間では6箇所で岩が突出していた。砂浜はこ れらの岩のある場所では沖へ突出していることから，こ の当時岩の先端を沿岸漂砂が回り込むことが可能であっ

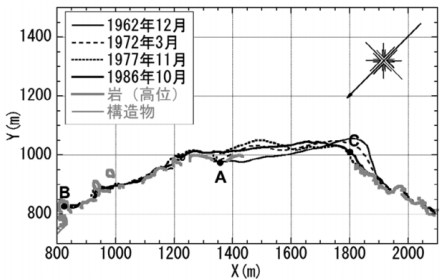

図-3＼cjkstart汀線変化（1962～1986年）

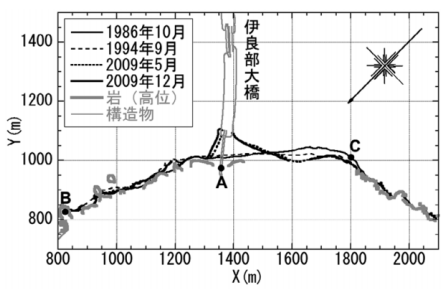

図-4＼cjkstart汀線変化（1986～2009年）

た.Aより南側ではCまでほぼ直線状の幅 $20 \mathrm{~m}$ の砂浜が 延び， Cで汀線の方向が急変するという砂嘴状の海浜で あった。砂嘴状の砂浜が南側で狭まったあとでは広い砂 浜はなくなり，突出した数多くの岩間に狭い海浜を残す のみであった。

伊良部大橋の建設が進んだ 2009 年 5 月には図-2(b) の ように，伊良部大橋の埋立地が南側および北側からの波 浪の作用を遮った結果，大橋の北側では南側からの波浪 作用を受けなくなり，同様に大橋の南側では北側からの 波浪作用がなくなった。この結果，伊良部大橋と伊良部 島の海岸線との交点へと向かう沿岸漂砂が生じ，周辺域 は侵食され，運ばれた砂が大橋の付け根に堆積すること になった。結果的に $\mathrm{AC}$ 間の海浜のうち大橋から離れた 場所の砂浜は大きく狭まった。

空中写真からは前浜とリーフ面との境界線（遷急線） を明瞭に読み取れることから，以後この境界線を汀線と 見なし，その位置を読み取った。図-3には1962年から 1986年まで 4 時期の汀線を示す. 1962年には $X=1800 \mathrm{~m}$ 付 近に先端を持つ舌状砂州が形成されていた。しかし時間 経過とともにこの舌状砂州は削り取られ，砂はA方向へ と移動し平坦な汀線へと変わった。この場合， $\mathrm{AC}$ 間で は著しい汀線変化が見られるのに対し $\mathrm{AB}$ 間での汀線変 化は $\mathrm{A} の$ 東側隣接部を除けば無視できる程度であった。 同様に図-4には1986年から 2009年12月までの汀線変化を 示す．伊良部大橋建設後はC 付近が大きく削り取られ， その砂が伊良部大橋の付け根にある A 付近へと移動した。

伊良部大橋建設後の 2009 年 5 月と 12 月において，伊良 部大橋付け根の汀線のうち, 南西側の汀線形状はほぼ一致 を示す。また北東側の汀線は2009年 12 月では 5 月と比較 して平行に前進している．これより，伊良部大橋の南西側 の汀線はほぼ平衡状態に至っているが，砂の一部は大橋の 
直下を越えて東側へと流出したこと，また北東側の汀線は 変形しつつもその法線の方向が卓越波向と直交しているこ とを示す。そこで大橋の南西側の汀線の中点, および北東 側の汀線の中点で法線を立て, その方向角を読み取ると, 南西側部分では $\mathrm{S} 22^{\circ} \mathrm{E}$ ，北東側では $\mathrm{N} 73^{\circ} \mathrm{E}$ となった。

次に, 図-3,4 おいて明暸な汀線変化が認められる区 間（X=830〜1950m）を対象として，1962年を基準とし た各年の海浜面積の変化量を算出した結果, 海浜面積は 1962 年から 1972 年の間に急激に増加した後，1977年以

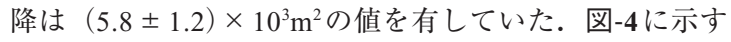
1986年 10 月と 2009年 12 月の汀線によれば，C付近での 汀線後退と大橋の付け根の $\mathrm{A}$ 付近での汀線前進が同時に 起きていることから, 両者から侵食面積と堆積面積を算 出するとそれぞれ $9,600 \mathrm{~m}^{2}, 10,700 \mathrm{~m}^{2}$ となって両者はほぼ バランスしている。またこの変化で注目されるのは，A 付近での堆砂が起こる場合, Aの北東側での汀線は大き く変化しておらず，大部分の砂は南西側すなわちC付近 から運び达まれていることである．現況で伊良部大橋の 付け根は栈橋構造を有し沿岸漂砂は通過可能である.こ のため栈橋下部を通過してC 側の砂が北東側へと運び込 まれたと言える。

\section{4. 前浜材料と縦断形変化}

図-2 (b) に示す伊良部大橋の南側隣接部の三角形状の 前浜において採取した海浜材料の粒度分析によれば，前 浜砂の中央粒径は $1.3 \mathrm{~mm}$ で, 均等係数が 2.49 のよく淘汰 された砂であった。粒度組成は, 中礫 $(2 \%)$, 細䃉 $(8 \%)$, 粗砂 $(65 \%)$, 中砂 $(25 \%)$, シルト $(0 \%)$ で あり, 大部分が粗砂と中砂で構成されていた。また前浜 勾配は約 $1 / 10$ であった。

伊良部大橋建設前の 2005 年 2 月 9 日と, 地形変化後の 2008年3月 8 日の汀線測量の結果をもとに, 図-2 (b) に示 す $\mathrm{a} 〜 \mathrm{f} の 6$ 測線における縦断形変化を調べた。図-5には 代表的に侵食域の測線 $\mathrm{a}$ と堆積域の測線 $\mathrm{f}$ 縦断形変化を 示す．な抢各図の破線はリーフの基盤面を示す．著しく 侵食が進んだ区域を横断する測線aでは, 侵食前にはバ 一ム高が $1.5 \mathrm{~m}$ であったが，リーフの基盤面（ $Z=-0.8 \mathrm{~m} ）$ から陸側， $Z=2.6 \mathrm{~m}$ までの間で侵食が進んだ。海浜と $Z=0 \mathrm{~m}$ との交点はこの間 $18 \mathrm{~m}$ 陸側に移動した（以下，汀線

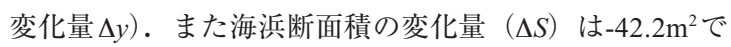
あった。な捜侵食域の陸側では一部堆積が見られるが, これは侵食によって波のうちあげ高が増大し, 砂がうち

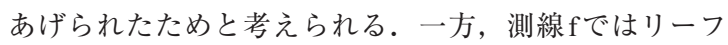
の基盤面 $(z=-1.2 \mathrm{~m})$ から陸側, ほぼ $z=2 \mathrm{~m}$ までの間で堆 積している. またバーム高は当初は $2 \mathrm{~m}$ と高かったが, 堆

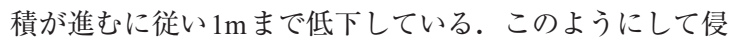
食域と堆積域で $\Delta y$ と $\Delta S$ を求めた結果, $\Delta S=2.7 \Delta y+2.4$ と
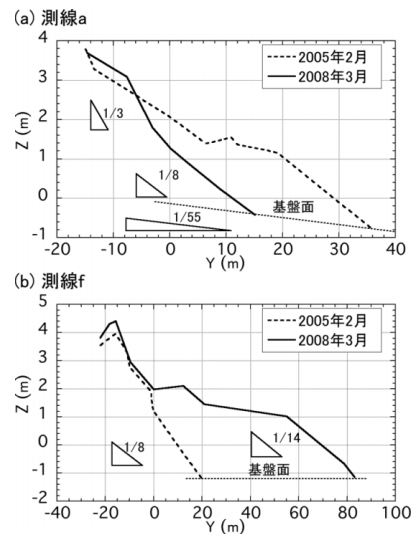

図-5 縦断形変化（2005年2月vs. 2008年3月）

いう線形関係が成立することが分かった，両者の勾配は 漂砂の移動高を与えるので, 移動高 $h$ は $2.7 \mathrm{~m}$ となる.ま た縦断形からバーム高は $2 \mathrm{~m}$ とすることができる.

既に伊良部大橋南側の侵食面積と大橋付近での堆積面 積がそれぞれ $9,600 \mathrm{~m}^{2} ， 10,700 \mathrm{~m}^{2}$ であることを示したが， これらの值に上記漂砂の移動高 $2.7 \mathrm{~m}$ を乗じると, 海浜土 砂量の変化量は $2.59 \times 10^{4} \mathrm{~m}^{3}, 2.89 \times 10^{4} \mathrm{~m}^{3}$ となる. 平均 土砂量は $2.74 \times 10^{4} \mathrm{~m}^{3}$ となった.

\section{5. 分析結果の要約と対策の基本的考え方}

長山の浜は伊良部島の南東端にあり, 島の両側から侵 入する波浪の作用を受けてきた。同時に沖合にはリーフ が発達し, リーフ起源の砂供給があった。これとよく似 た条件にあるのが宮古島の前浜である. 前浜の場合, 沖 合は来間島があるため海岸線に対する法線方向からの入 射波はなく, 宮古島と対岸の来間島の間の水道部を通過 する南東方向からの入射波と北西方向からの入射波の作 用がバランスして砂州を形成していたが，台風襲来によ り波浪バランスが崩れて舌状砂州の移動が生じた（菊池 ら，2002）。長山の浜も前浜と同じ機構で動的平衡状態 にあったと考えられる. しかし伊良部大橋の建設に伴い 埋立地が造られて波の場が大きく変化し, 波の遮蔽効果 が顕著に現れた結果, 大橋の南側では南側からの波の作 用のみ, 北側では北側からの波の作用のみとなった結果, 橋の取り付け部方向への強い沿岸漂砂が生じた。これが 海浜変形の原因と考えられる.

図-6を参照したとき，海浜変形は伊良部大橋の埋立地 造成に伴って橋梁の付け根に波の遮蔽域が形成され, 遮 蔽域の外から内側へと, すなわち C から A方向への沿岸 漂砂が起きたことに起因する. 南西側の背後地が侵食さ れて砂が汀線へ供給されると, 伊良部大橋の直下を沿岸 漂砂が通過可能なうちは大橋の東側の汀線 FGが F' G' のように前進するが，やがて大橋直下を漂砂が通過でき 


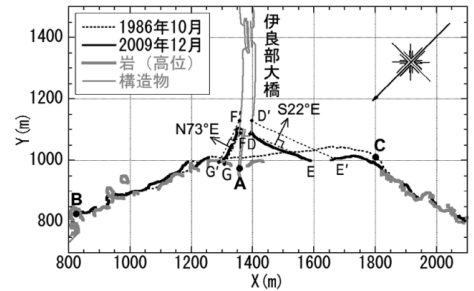

図-6 対策検討の模式図

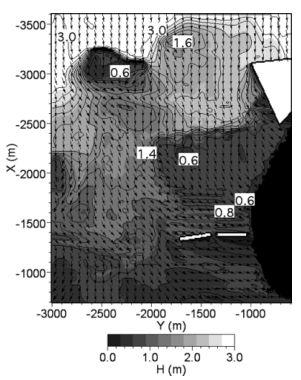

図-7 波高と波向の平面分布 $\left(H_{i}=3 \mathrm{~m}, T=12 \mathrm{~s}, \mathrm{~S} 38^{\circ} \mathrm{W}\right.$, H.W.L. $=$ E.L. $\left.+0.9 \mathrm{~m}\right)$

なくなると，大橋の南西側の汀線 $\mathrm{DE}$ が D' E' のように 前進する。すなわち安定な汀線を形成するには沿岸漂砂 を阻止する施設の南西側汀線を DEとほぼ平行にする必 要がある。合理的な案は，DEとほぼ平行な汀線が形成 されるよう AC間に数基の突堤を延ばした上で，伊良部 大橋の取り付け部の砂を除去し, 突堤の南西側で養浜を 行う手法と考えられる。

\section{BG モデルによる対策案の検討}

\section{（1）計算方法と計算条件}

地形変化計算にはBGモデル（芹沢ら，2006）を用い, 沿岸方向に $800 \mathrm{~m}$ ，岸沖方向に500m の区域を対象とした. 波浪場は，間瀬ら（1999）による不規則波を対象とする エネルギー平衡方程式法を用いて算出した。計算では砕 波滅衰項はDallyら（1984）のモデルを用いた。入射波 の方向スペクトルについては，ブレッドシュナイダー . 光易型周波数スペクトルと，光易型方向関数を組み合わ せたもの（合田，1990）とし，方向集中度は $S_{\max }=75$, 周 波数分割数は $N_{F}=3$, 方向分割数は $N_{\theta}=16$ とした．砕波係 数については，2009年の台風20号時において当海岸前面 で実測された最大波高 $H=0.75 \mathrm{~m}$ となるよう $\Gamma$ 值（水平床 での砤波限界波高水深比）を調整し，結果として $\Gamma=0.25$ と設定した。計算時の最小水深は $h_{0}=2 \mathrm{~m}$ とし，陸岸域 （地盤高 $Z \geqq \mathrm{E} . \mathrm{L} .+2 \mathrm{~m}$ 以上の地点）ではエネルギーを 0 と 置いた，入射波条件としては，入射波高を $H_{I}=3 \mathrm{~m} ， T=12 \mathrm{~s}$ とし，波向は2.で推定されたリーフエッジ外縁に直角方 向となる $\mathrm{S} 38^{\circ} \mathrm{W}$ とした。この波浪条件は，平良港沖の 1989 2002年の波浪観測デー夕によれば，年数回波（年

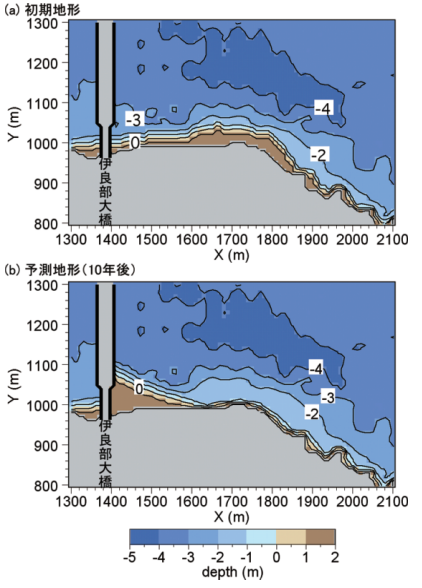

図-8 再現計算結果（伊良部大橋建設後の海浜変形）

間3日）に相当する。

計算では，まず伊良部大橋取り付け部建設前の自然状 態の前浜を復元する現況再現計算を行い，その上で養浜 を行うとともに離岸堤と突堤の配置と諸元を変えて 5 ケ 一スの計算を行った。養浜では大橋取り付け部から採取 した土砂 $V=32,000 \mathrm{~m}^{3}$ を南側へと移動させた。ケース 1 は 養浜のみ，ケース $2 \sim 5$ でもケース 1 と同量の養浜を行う が，土砂流出防止のためにケース $2 て ゙ は ~ T$ 字突堤を含む 離岸堤を設置し，ケース 3，4，5では突堤諸元を変えて 設置した上で養浜を行った。また，海浜変形は大橋の南 側が侵食され，その土砂が伊良部大橋付け根へと移動, 堆積することにより起きたものであるが，その際砂の一 部は大橋直下を通過して北側へと流出したものの，形成 された砂浜は伊良部大橋の橋軸と小さな角度を有する汀 線を形成していることから，伊良部大橋直下に不透過の 壁体を置くことでこれを模した。

\section{(2) 現況再現計算}

（1）で述べた計算条件のもとで現況再現計算を行った。 まず，伊良部大橋の建設区域とその南側に広がるリーフ を含む沿岸方向に $2,900 \mathrm{~m}$ ，岸沖方向に $2,400 \mathrm{~m}$ の海底地形 を与えて波浪場を計算した。潮位を $\mathrm{HWL}=\mathrm{EL}+0.9 \mathrm{~m}$ と設 定し，入射波高 $3 \mathrm{~m} ，$ 周期 $12 \mathrm{~s}$ の波を $\mathrm{S} 38^{\circ} \mathrm{W}$ 方向から入射 させた結果を図-7に示す，沖合からの入射波は伊良部大 橋の南側にある浅いリーフで減衰し，減衰した波が長山 の浜の汀線に対して斜め入射となる。 また大橋の付け根 付近には，南東側にある深みからの波浪も斜め入射し， 結果的に大橋の付け根方向への沿岸漂砂を誘起すること が分かる．現況再現計算の結果を図-8に示す．斜め入射 波のために図-8(a) に示す初期地形は直ちに南西部が侵 食され，砂が大橋の取り付け部へと運ばれて図-8(b) の ように三角形状の前浜が形成された。図-9は汀線変化を 示すが，汀線変化は初期に著しく進み時間経過とともに 


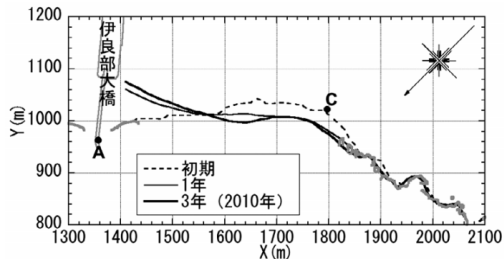

図-9＼cjkstart汀線変化

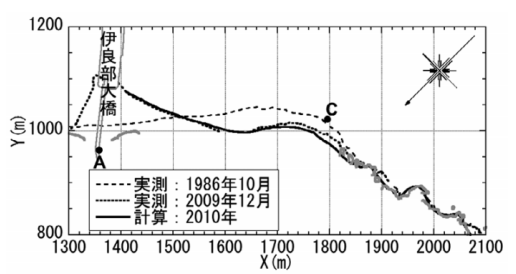

図-10 計算結果と実測の汀線比較

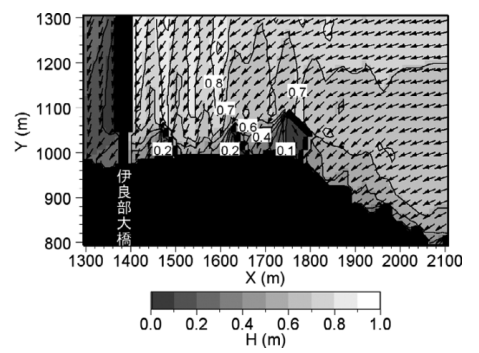

図-11 波高と波向の平面分布 (ケース 4 : 養浜+長さ $70 \mathrm{~m}$ の突堤)

緩やかになる。また図-10は実測と予測汀線の比較結果 を示すが，両者はよく一致している.

\section{(3) 対策案の検討}

突堤長を変えたケースのうち，ケース $3 ， 5$ では突堤長 が短いため養浜砂の流出が起きた。そこで，ここでは最 適案のケース4の結果を示す。このケースは, 図-6に示 す $\mathrm{AC}$ 間に突堤を設置するもので，海岸線の方向角が大 きく変わる $\mathrm{C}$ 点付近に突堤を配置してその南側で砂浜を 復元すると同時に, C点から北側 $300 \mathrm{~m}$ 区間の砂浜の回復 と大橋取り付け部での堆砂防止を目指す案である。この 場合, 突堤法線を汀線に直角方向とするのではなく, 来 襲波の卓越波向を考慮して斜めとした。一方， C点より 北側の海岸線は C 点近傍では凸状であるが，その北側で は緩やかな凹状になる，そこでこのような海岸線の特徵 を考慮して突堤位置を設定した。具体的には，C点に L 字突堤（先端部 $70 \mathrm{~m}$, 取付部 $50 \mathrm{~m}$ ）を設置し, C点の北 $120 \mathrm{~m}$ で, 海岸線が凸状から凹状へ変化する地点に突堤 (1) （堤長 $70 \mathrm{~m}$ ）を，さらにそこから $160 \mathrm{~m}$ 北に突堤(2)（堤長 $70 \mathrm{~m}$ ）を設けた。その上で伊良部大橋の付け根の砂を除 去し, 突堤の南西側で養浜を行った。図-11は波浪場の 計算結果である。突堤の北側背後では波が静穏となる. この波浪条件のもとで図-12（a）のように養浜を行い，波 を作用させた結果が図-12（b) である.ささらに汀線変化
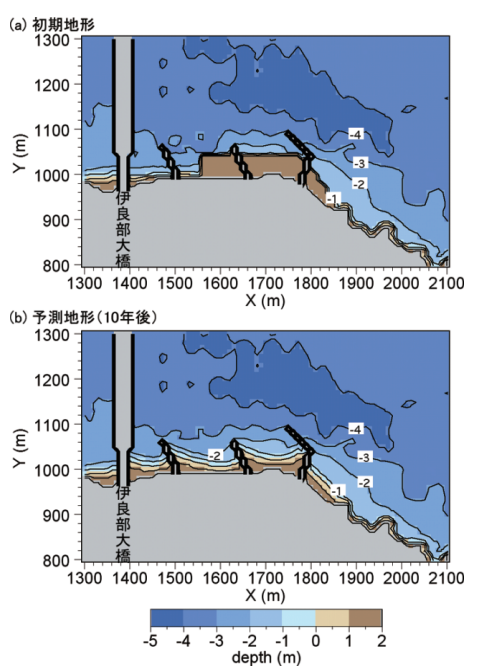

図-12 将来予測計算結果（ケース $4 ：$ 養浜+長さ $70 \mathrm{~m}$ の突堤）

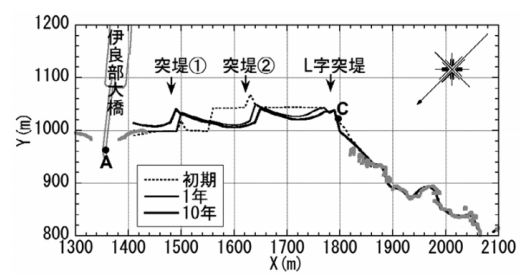

図-13 汀線変化（ケース4）

を図-13に示す。伊良部大橋側の 2 基の突堤間では砂浜が 形成され, 背後地の露出を防ぐことができる.

\section{7. まとめ}

養浜のみ, 離岸堤 + 養浜, 突堤などを用いた対策案の 検討によれば，最適案は突堤を用いた場合であり，伊良 部大橋側から堤長 $70 \mathrm{~m}$ の突堤 2 基と堤長 $120 \mathrm{~m}$ （先端部 $70 \mathrm{~m}$ ，取付部 $50 \mathrm{~m}$ ）のL字突堤を $160 \mathrm{~m}$ 間隔で設置した上 で, 伊良部大橋の付け根の砂を除去し, 突堤の南西側で 養浜を行えば目的をほぼ達成できることが分かった。

\section{参考文 献}

菊池昭男 - 宇多高明 - 西 隆一郎 - 三波俊郎 - 古池 鋼 - 芹沢 真澄（2002）：リーフ海岸における海面上昇起源の急激な 海浜変形 - 宮古島西部に位置する前浜海岸の例 - , 海岸 工学論文集, 第49巻, pp.596-600.

合田良實 (1990)：港湾構造物の耐破設計: 鹿島出版会, p.303. 芹沢真澄・宇多高明・三波俊郎・古池 鋼 (2006)：Bagnold 概念に基づく海浜変形モデル, 土木学会論文集 B, Vol.62, No.4, pp.330-347.

間瀬 肇・高山知司・国富将嗣・三島豊秋（1999）：波の回折 を考慮した多方向不規則波の変形計算モデルに関する研 究, 土木学会論文集, 628/II 48, pp.177-187.

Dally, W. R., Dean, R. G. and Dalrymple, R. A. (1984): A model for breaker decay on beaches: Proc. 19th Inter. Conf. on Coastal Eng., pp. 82-97. 